\title{
Article \\ Comparative Studies of Digestion Techniques for the Dissolution of Neodymium-Based Magnets
}

\author{
Mélodie Bonin ${ }^{1,2}\left(\mathbb{D}\right.$, Frédéric-Georges Fontaine ${ }^{1,3}$ and Dominic Larivière ${ }^{1,2, *}$ \\ 1 Chemistry Department, Université Laval, Québec City, QC G1V 0A6, Canada; \\ melodie.bonin.1@ulaval.ca (M.B.); frederic.fontaine@chm.ulaval.ca (F.-G.F.) \\ 2 Radioecology Laboratory, Université Laval, Québec City, QC G1V 0A6, Canada \\ 3 Canada Research Chair in Green Catalysis and Metal-Free Processes, Université Laval, \\ Québec City, QC G1V 0A6, Canada \\ * Correspondence: dominic.lariviere@chm.ulaval.ca; Tel.: +1-418-656-7250
}

check for

updates

Citation: Bonin, M.; Fontaine, F.-G.; Larivière, D. Comparative Studies of Digestion Techniques for the Dissolution of Neodymium-Based Magnets. Metals 2021, 11, 1149. https://doi.org/10.3390/met11081149

Academic Editor: Bernd Friedrich

Received: 30 June 2021

Accepted: 14 July 2021

Published: 21 July 2021

Publisher's Note: MDPI stays neutral with regard to jurisdictional claims in published maps and institutional affiliations.

Copyright: (c) 2021 by the authors. Licensee MDPI, Basel, Switzerland. This article is an open access article distributed under the terms and conditions of the Creative Commons Attribution (CC BY) license (https:// creativecommons.org/licenses/by/ $4.0 /)$.

\begin{abstract}
The digestion of neodymium (NdFeB) magnets was investigated in the context of recycling rare earth elements (i.e., $\mathrm{Nd}, \mathrm{Pr}, \mathrm{Dy}$, and $\mathrm{Tb}$ ). Among more conventional digestion techniques (microwave digestion, open vessel digestion, and alkaline fusion), focused infrared digestion (FID) was tested as a possible approach to rapidly and efficiently solubilize NdFeB magnets. FID parameters were initially optimized with unmagnetized magnet powder and subsequently used on magnet pieces, demonstrating that the demagnetization and grinding steps are optional.
\end{abstract}

Keywords: NdFeB magnets; critical metals; rare earth elements (REEs); recycling; focus infrared digestion; ICP-OES; electronic waste

\section{Introduction}

As electronic devices play an increasingly more important role in our lives, society needs to develop strategies to recover valuable metals from end-of-life electronic products. This need is driven by critical metal supply concerns, and by environmental issues with the rapid generation of electronic waste (e-waste) worldwide [1]. The annual global production of e-waste was approximately 53.6 million metric tons (Mt) in 2019 and is expected to increase to $74 \mathrm{Mt}$ by 2030 [1]. Because e-waste contains up to 69 elements from base to precious metals [1], e-waste mining has been proposed as a promising and cost-effective alternative to conventional mining [2]. However, it is estimated that less than $20 \%$ of the discarded e-waste is recycled at this time. This low recycling rate is partly attributed to the lack of proper recycling methods for most metals [1]. Therefore, there is a sustainable need to propose new and alternative strategies for e-waste recycling.

Besides precious and base metals, e-wastes also contain rare earth elements (REEs), which are increasingly used in high technology and clean energy applications [3]. REEs are present, for example, in common electronic components such as speakers, hard disk drives, and vibrators [4]. While REEs have relatively low concentrations in most bulk e-waste, the volume of end-of-life electronic devices discarded annually represents a great recycling opportunity. The presence of REEs within these devices comes mostly from neodymium (NdFeB) magnets [5]. NdFeB magnets are typically composed of up to $31 \mathrm{wt} \%$ REE [6]. Apart from Nd, which is the main REE, Dy, Pr, and Tb are also added to the magnet in various proportions depending on the application and quality of the magnets required [7]. The possibility of digesting NdFeB magnets into their isolated REE constituents is therefore a critical aspect of an effective recycling strategy.

While the recycling of REEs derived from NdFeB magnets in end-of-life electronic devices is not yet performed commercially, Rademaker et al. [7] emphasized that it would be technically feasible if efficient physical dismantling, separation, hydrometallurgical, and refining methods were available in the future. One challenge associated with REEs 
is the difficulty of isolating individual REEs from their neighbouring elements in the periodic table [8]. However, most separation techniques for REEs require the dissolution of solid matrices, and $\mathrm{NdFeB}$ magnets are no exception. Therefore, digestion of such magnets in a rapid, efficient, and cost-effective manner is an important aspect of a REEs recycling strategy.

Numerous researchers have investigated the dissolution of REEs from $\mathrm{NdFeB}$ magnets via various hydrometallurgical approaches (Table 1). Most procedures used variable acid types and concentrations and a two-step sample pre-treatment prior to the acid dissolution. This sample pre-treatment was driven by the need to demagnetize and pulverize the magnet to facilitate its manipulation and dissolution. These steps are time-consuming and potentially hazardous from a chemical and health perspective. For example, as the grinding of magnets leads to small particles, they can be inhaled and deposited within the respiratory system. The exposed magnet surface is increased for smaller particulates which can facilitate the ignition of metallic powders. Hoogerstraete et al. [9] reported a fire after opening a grinding mill containing NdFeB magnets. Sometimes, the heat generated during the grinding process can create a vacuum upon cooling, rendering the opening of the grinding mill challenging. Moreover, even though rare-earth magnets are brittle because they consist of agglomerated particulates (pressed and/or sintered), they are still a hard material and are sufficiently abrasive to damage steel, which can lead to premature wear of the equipment used for e-waste recycling. Grinding NdFeB magnets also requires powerful and resistant grinding equipment [10]. There is therefore a significant interest in assessing the dissolution performances of analytical procedures that do not require grinding and demagnetization processes.

Most dissolution approaches reported in the literature (Table 1) use elevated temperatures to accelerate $\mathrm{NdFeB}$ dissolution, usually heated with conventional heat sources such as hotplates and ovens. Recently, Helmeczi et al. [11] reported a rapid digestion of REEs in phosphoric acid by short-wavelength focused infrared radiation (FIR). They reported excellent recoveries and reproducibilities for REEs in various certified reference materials such as OREAS-465 (carbonatite supergene REE-Nb ore), OKA-2 (rare earths and thorium ore), and REE-1 (rare earths, zirconium, and niobium ore). These results suggest that FIR digestion could be a potential alternative to other heat sources for magnet dissolution and, potentially, alleviate previously mentioned sample pretreatments.

Table 1. Hydrometallurgical techniques published on the recycling of REEs from NdFeB magnets.

\begin{tabular}{|c|c|c|c|c|c|c|c|}
\hline $\begin{array}{l}\text { Magnets } \\
\text { Source }\end{array}$ & $\begin{array}{l}\text { Studied } \\
\text { Elements }\end{array}$ & Demagnetization & Particles Size & Pre-Treatment & $\begin{array}{l}\text { Leaching } \\
\text { Method }\end{array}$ & $\begin{array}{l}\text { Solubilization } \\
\text { REEs a/Fe (\%) }\end{array}$ & References \\
\hline $\begin{array}{l}\text { Magnetic } \\
\text { sludge }\end{array}$ & $\mathrm{Nd}, \mathrm{Dy}, \mathrm{Fe}, \mathrm{B}$ & $\begin{array}{c}\text { (Not } \\
\text { magnetized) }\end{array}$ & $<250 \mu \mathrm{m}$ & $\begin{array}{l}\text { Drying of the } \\
\text { sludge }\end{array}$ & $\begin{array}{c}1 \mathrm{M} \mathrm{HNO}_{3}+ \\
0.3 \mathrm{M} \mathrm{H}_{2} \mathrm{O}_{2} \\
80{ }^{\circ} \mathrm{C}^{\prime} \\
10 \mathrm{~mL} / \mathrm{g}, 5 \mathrm{~min}\end{array}$ & $98,81 / 15$ & $\begin{array}{l}\text { Rabatho, et al. } \\
\text { (2013) [12] }\end{array}$ \\
\hline $\begin{array}{l}\text { Manufacturing } \\
\text { waste magnets }\end{array}$ & $\mathrm{Nd}, \mathrm{Fe}, \mathrm{B}$ & $350^{\circ} \mathrm{C}, 15 \mathrm{~min}$ & $<297 \mu \mathrm{m}$ & - & $\begin{array}{c}3 \mathrm{~N} \mathrm{H}_{2} \mathrm{SO}_{4} \\
27{ }^{\circ} \mathrm{C} \\
50 \mathrm{~mL} / \mathrm{g} \\
15 \mathrm{~min} \\
\text { (ultrasound) }\end{array}$ & $100 / 100$ & $\begin{array}{l}\text { Lee, et al. } \\
\text { (2013) [10] }\end{array}$ \\
\hline $\begin{array}{l}\text { Manufacturing } \\
\text { waste magnets }\end{array}$ & $\mathrm{Nd}, \mathrm{Dy}, \mathrm{Fe}$ & $\begin{array}{c}\text { (Not } \\
\text { magnetized) }\end{array}$ & not mentioned & $\begin{array}{l}\text { Roasting at } \\
400{ }^{\circ} \mathrm{C}, 2 \mathrm{~h}\end{array}$ & $\begin{array}{c}1 \mathrm{M} \text { acetic acid, } \\
90^{\circ} \mathrm{C}, \\
100 \mathrm{~mL} / \mathrm{g}, \\
400 \mathrm{rpm}, 3 \mathrm{~h}\end{array}$ & $94,93 / 1$ & $\begin{array}{l}\text { Yoon, et al. } \\
\text { (2015) [13] }\end{array}$ \\
\hline HDD & $\mathrm{Nd}, \operatorname{Pr}$ & $\begin{array}{c}320^{\circ} \mathrm{C} \text {, time } \\
\text { not mentioned }\end{array}$ & $<250 \mu \mathrm{m}$ & - & $\begin{array}{c}2 \mathrm{M} \mathrm{H}_{2} \mathrm{SO}_{4} \\
70^{\circ} \mathrm{C} \\
20 \mathrm{~mL} / \mathrm{g} \\
15 \mathrm{~min}\end{array}$ & $\begin{array}{c}90 / \text { not } \\
\text { mentioned }\end{array}$ & $\begin{array}{c}\text { München, } \\
\text { Bernardes, and } \\
\text { Veit (2018) [14] }\end{array}$ \\
\hline Wind turbine & $\begin{array}{l}\mathrm{Nd}, \mathrm{Pr}, \mathrm{Dy}, \mathrm{Fe}, \\
\text { B, Al, Co }\end{array}$ & $310^{\circ} \mathrm{C}, 60 \mathrm{~min}$ & $<149 \mu \mathrm{m}$ & $\begin{array}{l}\text { Roasting at } \\
850{ }^{\circ} \mathrm{C}, 6 \mathrm{~h}\end{array}$ & $\begin{array}{c}0.5 \mathrm{M} \mathrm{HCl} \\
10 \mathrm{~mL} / \mathrm{g}^{\prime} \\
500 \mathrm{rpm}, 5 \mathrm{~h}\end{array}$ & $98,97 /<1$ & $\begin{array}{l}\text { Kumari, et al. } \\
\text { (2018) [15] }\end{array}$ \\
\hline HDD & $\mathrm{Nd}, \mathrm{Dy}, \mathrm{Fe}$ & $350{ }^{\circ} \mathrm{C}, 60 \mathrm{~min}$ & $<100 \mu \mathrm{m}$ & $\begin{array}{c}900 \mathrm{~W} \\
\text { microwave, } \\
\text { opened vessels, } \\
5 \text { min }\end{array}$ & $\begin{array}{c}0.5 \mathrm{M} \mathrm{HCl}, \\
70{ }^{\circ} \mathrm{C}, \\
25 \mathrm{~mL} / \mathrm{g}, \\
900 \mathrm{rpm}, 2 \mathrm{~h}\end{array}$ & $\begin{array}{l}\text { 56/low (not } \\
\text { mentioned) }\end{array}$ & $\begin{array}{c}\text { Tanvar, Kumar, } \\
\text { and Dhawan } \\
\text { (2019) [16] }\end{array}$ \\
\hline
\end{tabular}


Table 1. Cont.

\begin{tabular}{|c|c|c|c|c|c|c|c|}
\hline $\begin{array}{c}\text { Magnets } \\
\text { Source }\end{array}$ & $\begin{array}{l}\text { Studied } \\
\text { Elements }\end{array}$ & Demagnetization & Particles Size & Pre-Treatment & $\begin{array}{l}\text { Leaching } \\
\text { Method }\end{array}$ & $\begin{array}{l}\text { Solubilization } \\
\text { REEs }{ }^{a} / \mathrm{Fe}(\%)\end{array}$ & References \\
\hline HDD & $\mathrm{Nd}, \mathrm{Dy}, \mathrm{Fe}$ & $350{ }^{\circ} \mathrm{C}, 30 \mathrm{~min}$ & $<500 \mu \mathrm{m}$ & & $\begin{array}{c}2 \mathrm{M} \mathrm{H}_{2} \mathrm{SO}_{4} \\
27^{\circ} \mathrm{C} \\
20 \mathrm{~mL} / \mathrm{g} \\
15 \mathrm{~min}\end{array}$ & $100 / 100$ & $\begin{array}{l}\text { Erust, et al. } \\
\text { (2019) [17] }\end{array}$ \\
\hline HDD & $\mathrm{Fe}, \mathrm{Nd}, \mathrm{Co}, \mathrm{Ni}$ & $400{ }^{\circ} \mathrm{C}, 45 \mathrm{~min}$ & $<420 \mu \mathrm{m}$ & - & $\begin{array}{c}1.3 \mathrm{M} \\
\left(\mathrm{NH}_{4}\right)_{2} \mathrm{~S}_{2} \mathrm{O}_{8} \\
75{ }^{\circ} \mathrm{C} \\
50 \mathrm{~mL} / \mathrm{g} \\
15 \mathrm{~min}\end{array}$ & $99 / 64$ & $\begin{array}{l}\text { Ciro, et al. } \\
\text { (2019) [18] }\end{array}$ \\
\hline HDD & Nd, Pr, Dy, Fe & $350^{\circ} \mathrm{C}, 3 \mathrm{~h}$ & $\sim 2 \mathrm{~mm}$ & - & $\begin{array}{c}1 \mathrm{M} \mathrm{H}_{2} \mathrm{SO}_{4} \\
25^{\circ} \mathrm{C} \\
20 \mathrm{~mL} / \mathrm{g} \\
90 \mathrm{~min}\end{array}$ & $100 / 100$ & $\begin{array}{l}\text { Kumari, et al. } \\
(2020) \text { [19] }\end{array}$ \\
\hline HDD & $\begin{array}{c}\mathrm{Nd}, \mathrm{Pr}, \mathrm{Dy}, \mathrm{Tb} \\
\mathrm{B}, \mathrm{Fe}, \mathrm{Al}, \mathrm{Cu} \\
\mathrm{Ni}, \mathrm{Co}\end{array}$ & $350^{\circ} \mathrm{C}, 60 \mathrm{~min}$ & $<250 \mu \mathrm{m}$ & - & $\begin{array}{c}1.6 \mathrm{~N} \mathrm{HCl} \text { or } \\
\mathrm{H}_{2} \mathrm{SO}_{4} \\
20 \mathrm{~mL} / \mathrm{g} \\
5 \mathrm{~min}\end{array}$ & $100 / 100$ & Present work \\
\hline HDD & $\begin{array}{c}\mathrm{Nd}, \mathrm{Pr}, \mathrm{Dy}, \mathrm{Tb} \\
\mathrm{B}, \mathrm{Fe}, \mathrm{Al}, \mathrm{Cu}, \\
\mathrm{Ni}, \mathrm{Co}\end{array}$ & $\begin{array}{l}\text { No demagneti- } \\
\text { zation }\end{array}$ & $\begin{array}{l}\text { Coarsely } \\
\text { broken }\end{array}$ & - & $\begin{array}{c}1.6 \mathrm{~N} \mathrm{HCl} \text { or } \\
\mathrm{H}_{2} \mathrm{SO}_{4} \\
20 \mathrm{~mL} / \mathrm{g}, \\
\sim 30 \mathrm{~min} \text { for } \\
6 \times 3 \times 2 \mathrm{~mm} \\
\text { pieces }\end{array}$ & $100 / 100$ & Present work \\
\hline
\end{tabular}

a Presented as "Nd" (or mixed REEs) or "Nd, Dy" percentages.

In this article, we compared the dissolution of intact and pulverized magnets (both magnetized and demagnetized) by focused infrared digestion (FID) to other, more conventional dissolution techniques (microwave digestion, hot plate, and alkaline fusion).

\section{Materials and Methods}

\subsection{Materials and Reagents}

Two different samples were used in this study. The first sample, for method comparison and optimization, was prepared from magnets obtained from hard disk drives (HDD) collected in electronic waste bins located on the main campus at Laval University (Quebec City, QC, Canada) and separated from their brackets. The second sample, for the study concerning the dissolution of unaltered magnets, consisted of cylindrical magnets of $0.751 \pm 0.006 \mathrm{~g}$ (6 mm in diameter and $2 \mathrm{~mm}$ in height) manufactured as one single batch, purchased from MagnetsShop (Culver City, CA, USA). These magnets were physically cleaved into similar fractions to enable the acid to penetrate beyond the protective $\mathrm{Ni}-\mathrm{Cu}-\mathrm{Ni}$ coating.

Nanopure water $\left(18.2 \mathrm{M} \Omega \cdot \mathrm{cm}\right.$ at $\left.25^{\circ} \mathrm{C}\right)$ obtained using a Milli-Q system (Millipore, Bedford, MA, USA) was used to dilute the solutions. Standard solutions $\left(1 \mathrm{~g} \cdot \mathrm{L}^{-1}\right)$ of $\mathrm{Al}, \mathrm{B}$, $\mathrm{Co}, \mathrm{Cu}, \mathrm{Dy}, \mathrm{Fe}, \mathrm{Nb}, \mathrm{Nd}, \mathrm{Ni}, \mathrm{Pr}, \mathrm{Rh}$ (ISTD), and Tb, purchased from PlasmaCal (SCP Science, Baie d'Urfée, QC, Canada), were used to prepare calibration standards. Concentrated ACS-grade $\mathrm{H}_{2} \mathrm{SO}_{4}$ (Fisher, Ottawa, ON, Canada), and trace metal grade $\mathrm{HCl}$ and $\mathrm{HNO}_{3}$ (VWR, Mississauga, ON, Canada) were used for sample digestion. Unless stated otherwise, all the confidence intervals represent a confidence level of $95 \%$.

\subsection{Demagnetisation and Grinding}

Hard disk drive magnets (237 g) were demagnetized by thermal demagnetization based on the procedure proposed by Tanvar et al. [16]; the intact magnets were heated in a muffle furnace at $350^{\circ} \mathrm{C}$ in a porcelain crucible for $1 \mathrm{~h}$. Then, the demagnetized magnets were placed in a steel dish with grinding rings and ground with an 8500 Shatterbox mill (SPEX SamplePrep, Metuchen, NJ, USA) during successive cycles lasting 70, 50, and $40 \mathrm{~s}$. Between each cycle, the ground sample was sifted through a $250 \mu \mathrm{m}$ (mesh \#60) brass sieve. Pieces larger than $250 \mu \mathrm{m}$ were reintroduced to the steel dish for the next cycle. The resulting powder had a final mass of $216 \mathrm{~g}$, representing 91\% of the original mass. The difference between the initial and final masses can be explained by the presence of 
unground particles (13 g) that were larger than $250 \mu \mathrm{m}$ after the last grinding cycle, and losses during grinding and sieving operations.

The particle size of the ground magnets was analyzed with 53 and $150 \mu \mathrm{m}$ (mesh \#270 and \#100) sieves with a W.S. Tyler RX-29 Ro-Tap Sieve shaker (Laval Lab, Laval, QC, Canada) for $15 \mathrm{~min}$, and each collected fraction was weighed. The mass loss from sieving represents less than $0.5 \%$ of the total mass used. For all the grinding and sieving steps, the sieves used were W.S. Tyler 12 inch $(30.5 \mathrm{~cm}$ ) brass sieves (Laval Lab, ibid.) with a PM4000 balance (Mettler Toledo, Mississauga, ON, Canada).

\subsection{Elemental Analyses}

The elemental composition of magnets was determined by inductively coupled plasma-optical emission spectroscopy (ICP-OES, iCAP 7000 Series, Thermo Scientific, Montréal, QC, Canada) equipped with a pneumatic concentric nebulizer. Table 2 presents the ICP-OES operating conditions. X-ray fluorescence (XRF) analyses were also used on some digestion residues to determine their elemental constituents. XRF analyses were performed in 3 replicates of $30 \mathrm{~s}$ for each filter (Na-S, Ni-Ag, $\mathrm{Cr}-\mathrm{Co}$, and $\mathrm{Cl}-\mathrm{V})$ using a MiniPal4 (Malvern Panalytical, Québec, QC, Canada).

Table 2. ICP-OES operating conditions.

\begin{tabular}{cc}
\hline Instrumental Parameters & iCAP 7000 Series ICP-OES \\
\hline RF Power $(\mathrm{W})$ & 1150 \\
\hline Plasma gas flow $(\mathrm{L} / \mathrm{min})$ & 0.5 \\
\hline Auxiliary gas flow $(\mathrm{L} / \mathrm{min})$ & 0.5 \\
\hline Nebulizer gas flow $(\mathrm{L} / \mathrm{min})$ & Radial $(\mathrm{Fe}, \mathrm{Nd})$, Axial (others) \\
\hline Analysis mode & 5 \\
\hline Stabilization Time $(\mathrm{s})$ & 1.8 \\
\hline Sample flow rate $(\mathrm{mL} / \mathrm{min})$ & $\mathrm{Al}(309.271), \mathrm{B}(249.773), \mathrm{Co}(228.616), \mathrm{Cu}(224.700$, \\
& $324.754), \mathrm{Dy}(353.170), \mathrm{Fe}(238.204,259.940)$, \\
& $\mathrm{Nb}(309.418), \mathrm{Nd}(401.225,406.109), \mathrm{Ni}(216.556$, \\
Wavelength $(\mathrm{nm})$ & $221.647), \operatorname{Pr}(422.535), \mathrm{Tb}(350.917)$ \\
\hline
\end{tabular}

\subsection{Leaching}

\subsubsection{Total Dissolution of the NdFeB Magnets}

To evaluate the elemental composition of ground magnets, four dissolution techniques were used: (1) closed-vessel acid digestion (CVAD, SCP Science, Baie d'Urfée, QC, Canada); (2) microwave (MWD, CEM corporation, Matthews, NC, USA); (3) focused infrared digestion (FID, Coldblock, Niagara Falls, ON, Canada), and (4) alkaline fusion (AF, Malvern Panalytical, Québec, QC, Canada). Table 3 presents the conditions used for each type of dissolution technique. Note that for FID and AF, the temperature ramping was extremely rapid, and boiling and melting temperatures, respectively, were obtained in less than a minute in both cases. The choice of a mixture of concentrated $\mathrm{HCl}$ and $\mathrm{HNO}_{3}$ in an 8-to-2 ratio for acid digestion was based on the operating conditions reported by Berghof [20] for the dissolution of permanent magnets. The choice of $3 \mathrm{M}$ of $\mathrm{HNO}_{3}$ as a dissolution medium for alkaline fusion was based on the procedure published by Milliard et al. [21] concerning the dissolution of refractory species in environmental matrices.

\subsubsection{Leaching Experiments}

Experiments on the leaching of elements from the NdFeB powder were conducted with $1 \mathrm{~g}$ of ground magnetic material by FID using the design of experiments (DOE) performed using JMP Pro (Version 14.3, SAS Institute, Cary, NC, USA). The parameters used for this optimization process on the FID are presented in Table 4. 
Table 3. Operating conditions used for the complete dissolution of ground magnets.

\begin{tabular}{ccccc}
\hline Digestion Technique & CVAD & MWD & FID & AF a \\
\hline Instrument & DigiPrep Jr 12 pos. & Mars 5 & 6 channels ColdBlock & M4 Fluxer \\
\hline $\begin{array}{c}\text { Amount of ground } \\
\text { magnet used }(\mathrm{g})\end{array}$ & 0.5 & 0.25 & 1.0 & 0.1 \\
\hline Volume of acid $(\mathrm{mL})$ & $30 \mathrm{~mL}$ & $10 \mathrm{~mL}$ & $25 \mathrm{~mL}$ & $100 \mathrm{~mL}$ \\
\hline Nature of the acid used & $\mathrm{HCl:HNO}(8: 2)$ & $\mathrm{HCl}_{\mathrm{HNO}}(8: 2)$ & $\mathrm{HCl:HNO}_{3}(8: 2)$ & $3 \mathrm{M} \mathrm{HNO}_{3}$ \\
\hline Digestion procedure & $\begin{array}{c}\text { Ramp ca. } 30 \mathrm{~min}, \\
240 \mathrm{~min} \text { at } 100{ }^{\circ} \mathrm{C}\end{array}$ & $\begin{array}{c}\text { Ramp } 25 \mathrm{~min}, \text { hold } \\
15 \mathrm{~min}, 1600 \mathrm{~W} \text { at } 100 \%\end{array}$ & $\begin{array}{c}15 \mathrm{~min} \text { at } 100 \% \text { power } \\
\text { for both lamps }\end{array}$ & See Milliard et al. [21] \\
\hline
\end{tabular}

a Fusion was performed using a 20:1 ( 2 g) ratio of LiT/LiB/LiBr 49.5/49.5/1\% flux to sample (Malvern Panalytical, Québec, QC, Canada), which was subsequently dissolved under the acidic conditions presented.

Table 4. Values used during DOE optimization process of the focused infrared digestion of ground magnets.

\begin{tabular}{cccc}
\hline Nominal Variables & Value $\mathbf{1}$ & Value 2 & \\
\hline Acid type & $\mathrm{HCl}$ & $\mathrm{H}_{2} \mathrm{SO}_{4}$ & \\
\hline Numerical Variables & Low-Value & Mid-Value & High-Value \\
\hline Acid concentration $(\mathrm{N})$ & 1 & 2 & 3 \\
Acid-to-sample ratio $(\mathrm{mL} / \mathrm{g})$ & 10 & 20 & 30 \\
Dissolution time $(\mathrm{s})$ & 300 & 450 & 600 \\
Lamp power $(\%)$ & 80 & 90 & 100 \\
\hline
\end{tabular}

After optimization, the following optimal leaching methodology was used for FID: either $20 \mathrm{~mL}(1.6 \mathrm{~N})$ or $10 \mathrm{~mL}(3.2 \mathrm{~N})$ of $\mathrm{HCl}$ or $\mathrm{H}_{2} \mathrm{SO}_{4}$, per gram of ground $\mathrm{NdFeB}$, is necessary to quantitatively (>99.9\%) solubilize the rare earth elements in 5 min with a lamp power of $100 \%$. For the trials on unaltered magnets, $7.5 \mathrm{~mL}$ of $3.2 \mathrm{~N}$ of $\mathrm{H}_{2} \mathrm{SO}_{4}$ was used for about $0.75 \mathrm{~g}$ of magnetic material.

\section{Results and Discussion}

\subsection{Particle Size Distribution of the Ground Demagnetized NdFeB Magnets}

The particle size plays an important role in the dissolution process of ground magnets. The particle size distribution of ground NdFeB magnets obtained from HDD are presented in Table 5.

Table 5. Mass percentage composition as a function of the particle size of the ground NdFeB magnet powder obtained from HDD.

\begin{tabular}{cc}
\hline Particle Size $(\boldsymbol{\mu m})$ & Mass Percentage $(\%)$ \\
\hline$<53$ & 42 \\
$54-150$ & 34 \\
$151-250$ & 24 \\
\hline
\end{tabular}

The particle size distribution shows that most of the ground magnet powder $(76 \%)$ was reduced to particles smaller than $151 \mu \mathrm{m}$. The three fractions were pooled together and used for the remaining trials.

\subsection{Elemental Composition of Ground Demagnetized NdFeB Magnets}

To properly assess various leaching approaches, the elemental composition of the powdered magnet must be known exactly. Four total dissolution approaches were compared: closed-vessel acid digestion (CVAD), microwave digestion (MW), focused infrared digestion (FID), and alkaline fusion (AF). The elemental composition was determined by ICP-OES. The instrument response was validated by analyzing $\mathrm{Al}, \mathrm{Cu}, \mathrm{Dy}, \mathrm{Fe}, \mathrm{Nb}, \mathrm{Nd}, \mathrm{Ni}$, 
and Pr in the certified reference material REE-1 (CanmetMINING, Ottawa, ON, Canada). The REE-1 material was prepared for ICP-OES analysis by AF using $0.4 \mathrm{~g}$ of the material with $1.2 \mathrm{~g}$ of flux. Other parameters were as presented in Table 3. Table 6 presents the elemental composition of powdered NdFeB magnets determined by ICP-OES based on the total dissolution technique used.

Table 6. Elemental composition (\%) of the powdered NdFeB sample determined by ICP-OES based on the total digestion used.

\begin{tabular}{|c|c|c|c|c|}
\hline \multirow[b]{2}{*}{ Element } & \multicolumn{4}{|c|}{ Digestion Technique } \\
\hline & $\begin{array}{l}\text { Closed-Vessel Acid } \\
\qquad(n=6)\end{array}$ & $\begin{array}{l}\text { Microwave } \\
\quad(n=2)\end{array}$ & $\begin{array}{l}\text { Focused Infrared } \\
\qquad(n=3)\end{array}$ & $\begin{array}{l}\text { Alkaline Fusion } \\
\qquad(n=3)\end{array}$ \\
\hline $\mathrm{Fe}$ & $64 \pm 1$ & $67 \pm 2$ & $65 \pm 2$ & $67 \pm 3$ \\
\hline $\mathrm{Nd}$ & $24.5 \pm 0.7$ & $25.6 \pm 0.9$ & $26.0 \pm 0.6$ & $25 \pm 2$ \\
\hline Pr & $3.4 \pm 0.1$ & $3.6 \pm 0.1$ & $3.5 \pm 0.2$ & $3.3 \pm 0.3$ \\
\hline $\mathbf{N i}$ & $1.8 \pm 0.2$ & N.D. & $1.9 \pm 0.1$ & $1.7 \pm 0.3$ \\
\hline Dy & $1.57 \pm 0.04$ & $1.61 \pm 0.08$ & $1.5 \pm 0.2$ & $1.5 \pm 0.1$ \\
\hline B & $1.04 \pm 0.02$ & $0.93 \pm 0.03$ & $1.0 \pm 0.1$ & N.M. \\
\hline Co & $1.02 \pm 0.02$ & $1.02 \pm 0.01$ & $1.00 \pm 0.07$ & $1.0 \pm 0.1$ \\
\hline Al & $0.43 \pm 0.02$ & $0.50 \pm 0.01$ & $0.5 \pm 0.1$ & $0.49 \pm 0.07$ \\
\hline $\mathrm{Nb}$ & $0.44 \pm 0.08$ & $0.4 \pm 0.1$ & $0.223 \pm 0.005$ & $0.35 \pm 0.02$ \\
\hline $\mathrm{Cu}$ & $0.20 \pm 0.02$ & N.D. & $0.17 \pm 0.03$ & $0.16 \pm 0.02$ \\
\hline $\mathrm{Tb}$ & $0.07 \pm 0.02$ & $0.09 \pm 0.05$ & $0.09 \pm 0.03$ & $0.08 \pm 0.01$ \\
\hline Total & $99 \pm 2 \%$ & $101 \pm 4 \%$ & $100 \pm 4 \%$ & $100 \pm 6$ \\
\hline
\end{tabular}

N.M.-not measurable, due to the addition of borate flux. N.D.- not determined.

The results obtained from four distinct digestion approaches for ground magnets led to a relatively consistent elemental composition except for $\mathrm{Nb}$. This suggests that the sample used was sufficiently homogeneous to be used for leaching comparisons, which is discussed in the next section. As the digestates were filtered prior to ICP-OES analysis, a black residue was noticeable on the filters used for the samples digested by CVAD and FID. Pre-weighed filters were used to determine the mass fraction of the undissolved magnet powder. After filtration, they were washed with water, dried, and weighed using an analytical balance. The filters were then subjected to elemental analysis by XRF (Figure 1). It was determined that the residue represents $0.40 \pm 0.08 \%(\sigma=1 \mathrm{SD})$ of the ground magnet mass used initially.

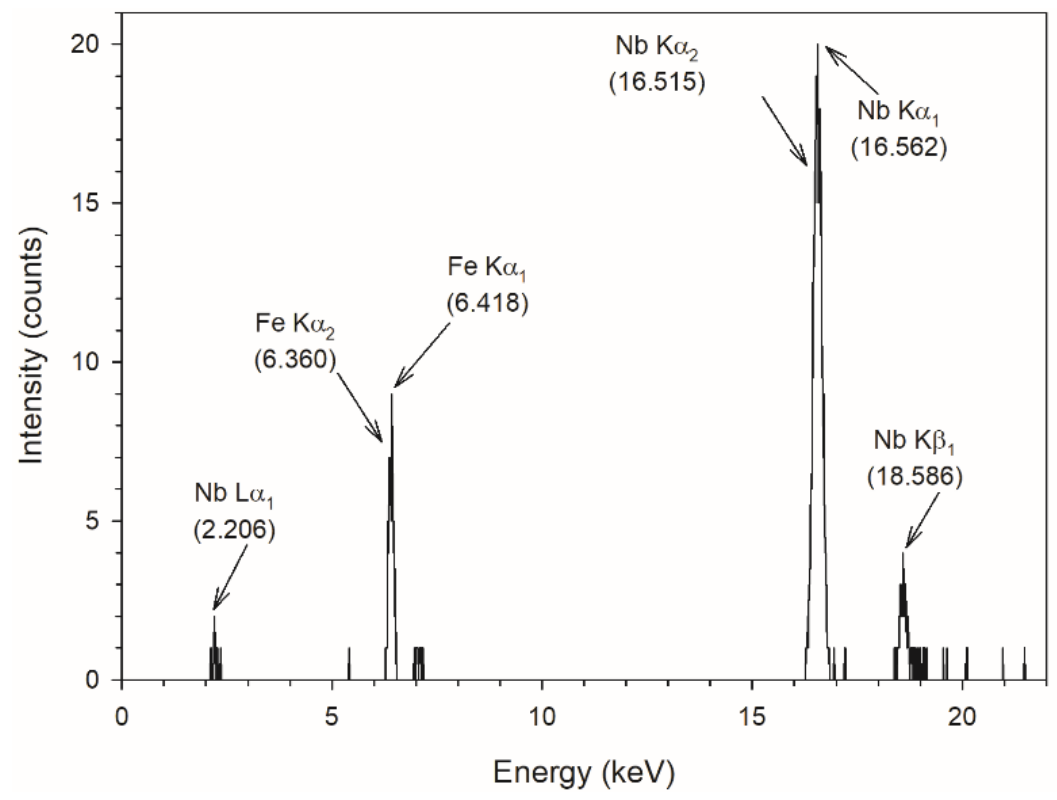

Figure 1. XRF spectrum of the residue present after FID. 
The XRF analysis showed that the residue is composed of $\mathrm{Nb}$ and $\mathrm{Fe} . \mathrm{Nb}$ is present in some $\mathrm{NdFeB}$ magnets to increase resistance to corrosion and enhance some magnetic properties [22,23]. Its presence in our powdered sample is not unexpected, because of the refractory nature of niobium oxides [24]. We suspect that the presence of Fe is the result of incomplete washings of the filter surface. Except for traces of $\mathrm{Nd}$ and $\mathrm{Fe}$, all four digestion techniques were effective to completely dissolve ground demagnetized magnets.

\subsection{Leaching of Powdered and Demagnetized Magnets}

While complete dissolution of the magnets is mandatory for comparing the digestion techniques and determining the degree of leaching, it is not necessary from the perspective of developing a hydrometallurgical strategy for the recycling of rare earth elements in magnets. Helmeczi et al. [11] recently reported the rapid dissolution of REEs in mineral and environmental matrices using FID. As FID also demonstrated equivalent dissolution performances to other digestion techniques for the complete digestion, this approach was investigated for leaching purposes through a design of experiments (DOE) approach.

\subsubsection{Design of Experiments}

While the previous digestion procedure, which used a mixture of $\mathrm{HCl}$ and $\mathrm{HNO}_{3}$, was certainly effective to completely dissolve powdered magnets, total digestion is not necessary for the recycling of REEs. The cost of nitric acid and its oxidative characteristics have limited its use in the hydrometallurgical separation of REEs in favor of $\mathrm{HCl}$ and $\mathrm{H}_{2} \mathrm{SO}_{4}$ [25]. Thus, an investigation of the leaching of ground demagnetized magnets was performed in either $\mathrm{HCl}$ or $\mathrm{H}_{2} \mathrm{SO}_{4}$. Five parameters were assessed through a DOE approach (Table 7). A first assessment of the DOE results showed that no parameter had a statistically significant impact on the dissolution. However, by removing either the acid type, dissolution time, or lamp power factors, the results showed that the concentration of acid, the acid-to-sample ratio, and their two-factor interaction were the only significant factors in the leaching of REEs. This suggests that the number of moles of acid was the main parameter for this leaching optimization. Experimentally, it was also determined that the low value used for the dissolution time (i.e., 300 s) set in the DOE was exceedingly sufficient to completely dissolve powdered magnets.

Table 7. Statistical importance of the DOE factors according to a 5- and 4-factor analysis.

\begin{tabular}{|c|c|c|}
\hline Source & Log Worth ${ }^{a}$ for 5 Factors & $\log _{\text {Worth }}{ }^{a}$ for 4 Factors $b$ \\
\hline Concentration & 1.734 & 3.506 \\
\hline Ratio & 1.724 & $\overline{\overline{3.484}}$ \\
\hline Concentration * Ratio & 1.567 & $\underline{3.142}$ \\
\hline Acid & 0.448 & $\overline{\overline{0.706}}$ \\
\hline Intensity * Time & 0.354 & \\
\hline Intensity * Ratio & 0.240 & 0.360 \\
\hline Time ${ }^{*}$ Acid & 0.209 & \\
\hline Time & 0.137 & \\
\hline Concentration * Acid & 0.137 & 0.223 \\
\hline Ratio * Acid & 0.131 & 0.215 \\
\hline Intensity * Acid & 0.130 & 0.189 \\
\hline Intensity * Concentration & 0.091 & 0.145 \\
\hline Intensity & 0.089 & 0.127 \\
\hline Time * Ratio & 0.064 & \\
\hline Time ${ }^{*}$ Concentration & 0.026 & \\
\hline
\end{tabular}

${ }^{\mathrm{a}} \mathrm{A} \log$ worth value of minimum 2 is required for a factor to be considered significant. ${ }^{\mathrm{b}}$ Dissolution time (Time) factor removed.

To adequately determine the quantity of acid required per gram of powdered magnet to completely dissolve REEs, tests were performed in $\mathrm{HCl}$ and $\mathrm{H}_{2} \mathrm{SO}_{4}$ by varying the number of moles of acid used per gram of magnet. The results are presented for $\mathrm{Nd}$ as a representative of the REEs in Figure 2. 


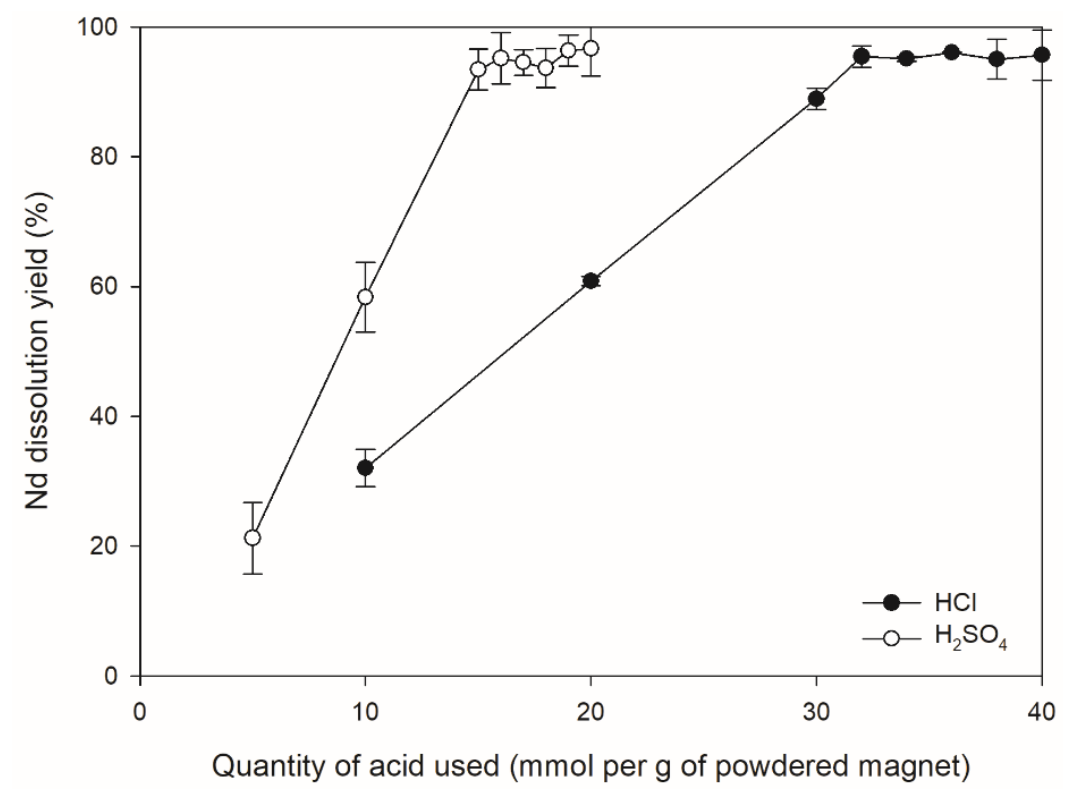

Figure 2. $\mathrm{Nd}$ dissolution yield (\%) as a function of the amount of acid $\left(\mathrm{HCl}\right.$ or $\mathrm{H}_{2} \mathrm{SO}_{4}$, in mmol) for $1 \mathrm{~g}$ of powdered magnet after a digestion by FID (300 s).

This test highlights the fact that the quantity of acid available to react with the powder is the limiting factor in the dissolution of REEs using FID. The required quantity of $\mathrm{H}_{2} \mathrm{SO}_{4}$ ( $16 \mathrm{mmol} / \mathrm{g}$ of ground magnet) is exactly half of the needed $\mathrm{HCl}(32 \mathrm{mmol} / \mathrm{g})$, which is consistent with the balanced redox formulas (Equations (1) and (2)) for both acids. As two atoms of REEs are being oxidized to a trivalent oxidation state, six $\mathrm{H}^{+}$cations need to be reduced, which can be found in either three molecules of $\mathrm{H}_{2} \mathrm{SO}_{4}$ or six of $\mathrm{HCl}$, hence the need for twice as much $\mathrm{HCl}$ as $\mathrm{H}_{2} \mathrm{SO}_{4}$. A similar logic can be applied to iron, one of the main components of the magnet. Based on the composition of the powdered magnet, it was calculated (from composition obtained by FID) that approximately $34 \mathrm{mmol}$ of $\mathrm{H}^{+}$was required to oxidize and dissolve the magnet, which is coherent with the quantity found experimentally.

$$
\begin{gathered}
2 \mathrm{REE}_{(\text {metallic) }}+6 \mathrm{HCl}_{(\mathrm{aq})} \rightarrow 2 \mathrm{REE}^{3+}{ }_{(\mathrm{aq})}+6 \mathrm{Cl}^{-}{ }_{(\mathrm{aq})}+3 \mathrm{H}_{2(\mathrm{~g})}+\Delta, \\
2 \mathrm{REE}_{(\text {metallic) }}+3 \mathrm{H}_{2} \mathrm{SO}_{4(\mathrm{aq})} \rightarrow 2 \mathrm{REE}^{3+}{ }_{(\mathrm{aq})}+3 \mathrm{SO}_{4}{ }^{2-}{ }_{(\mathrm{aq})}+3 \mathrm{H}_{2(\mathrm{~g})}+\Delta,
\end{gathered}
$$

Based on these observations, the following final leaching methodology can be proposed for FID: either $20 \mathrm{~mL}$ of $1.6 \mathrm{~N}$ or $10 \mathrm{~mL}$ of $3.2 \mathrm{~N}$ of $\mathrm{HCl}$ or $\mathrm{H}_{2} \mathrm{SO}_{4}$ per gram of $\mathrm{NdFeB}$ powder will be sufficient to completely solubilize the rare earths.

As stated previously, FID totally leached REEs from magnets, even with the shortest dissolution time tested $(5 \mathrm{~min})$. This suggests that the power output associated with the FID is more than sufficient to enable the complete dissolution of REEs. Thus, the $\mathrm{Nd}$ dissolution yield was monitored for dissolution times ranging from 60 to $300 \mathrm{~s}$ to determine how long, at full lamp power, it would take to achieve complete dissolution. No statistical differences in $\mathrm{Nd}$ dissolution yield were noted in the time range selected, except for the trial that ran for only $60 \mathrm{~s}(94 \%)$.

\subsubsection{Leaching Performance Comparisons (CVAD, FID)}

To determine whether there is a significant advantage in using FID for the leaching of REEs from magnets, the FID approach was compared to closed-vessel acid digestion (CVAD). The digestion of powdered $\mathrm{NdFeB}$ magnet was easily achieved in $300 \mathrm{~s}$. As with FID, shorter dissolution times (60 to 300 s) were also investigated with CVAD. However, this technique required longer times-more than $120 \mathrm{~s}$ - to achieve complete digestion and quantitative dissolution ( $84 \%$ and $95 \%$ for 60 and 120 s, respectively). 
Comparisons of the dissolution yields for FID and CVAD are presented in Figure 3. Statistically, both techniques yielded similar results when $10 \mathrm{~mL}$ of acid was used. Samples prepared using $20 \mathrm{~mL}$ of acid per gram showed lower yields with CVAD than FID. This difference could be explained by the short digestion time used (300 s), which does not allow the larger volume of the solution $(20 \mathrm{~mL})$ to be properly heated; this highlights the importance of heat in the rapidity of the digestion process. When performed at room temperature and a contact time of $300 \mathrm{~s}$, the dissolution yields of REEs (i.e., $\mathrm{Nd}, \mathrm{Pr}, \mathrm{Dy}$, and $\mathrm{Tb}$ ) reached $80-90 \%$ with $\mathrm{H}_{2} \mathrm{SO}_{4}$ and $30-45 \%$ with $\mathrm{HCl}$. As dissolution at room temperature with $\mathrm{H}_{2} \mathrm{SO}_{4}$ was more effective, further trials used $\mathrm{H}_{2} \mathrm{SO}_{4}$. However, it should be noted that $\mathrm{HCl}$ is also a very suitable acid for such purposes and could be a judicious choice if the subsequent separation scheme is performed in this media.
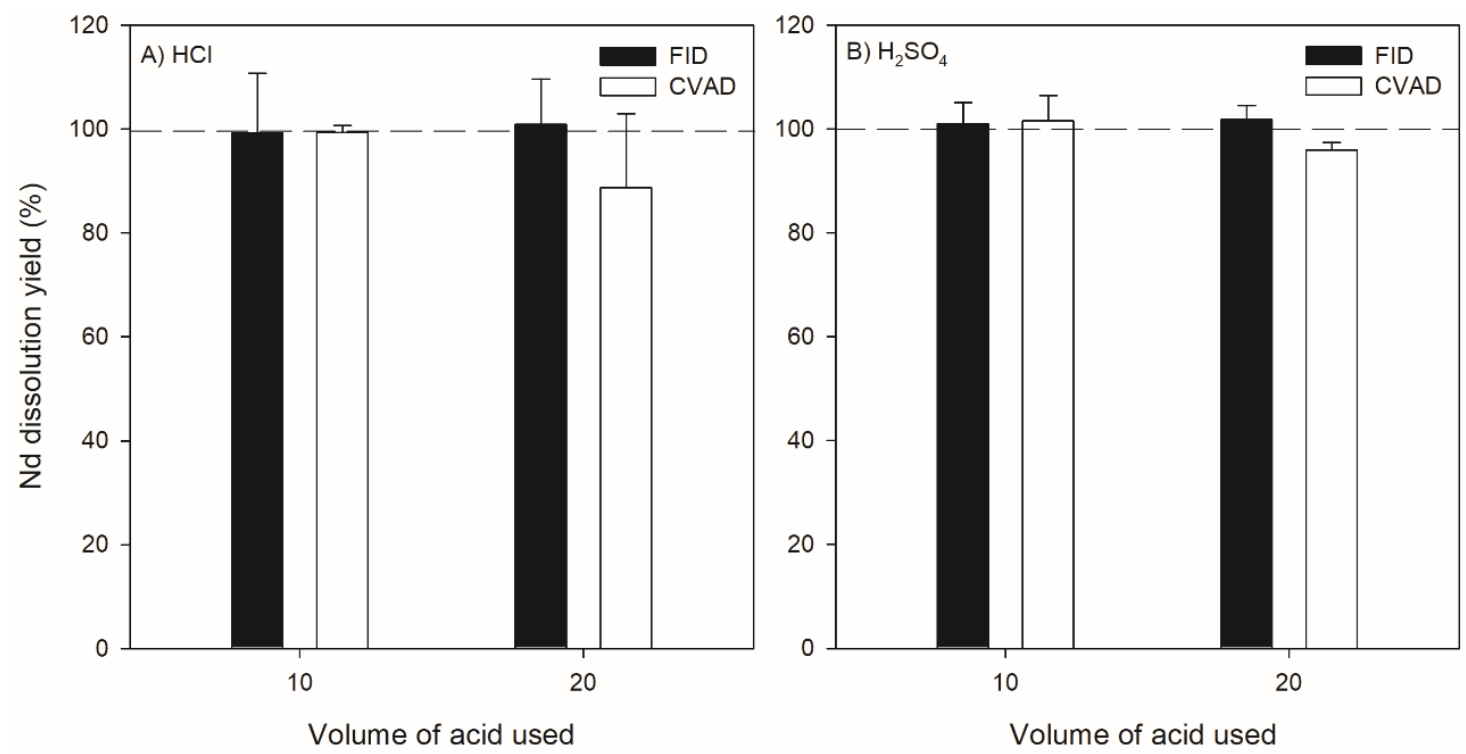

Figure 3. Comparison of FID and CVAD for the digestion of $1 \mathrm{~g}$ of magnet powder during $300 \mathrm{~s}$ with $10 \mathrm{~mL}$ of $3.2 \mathrm{~N}$ or $20 \mathrm{~mL}$ of $1.6 \mathrm{~N}$ of $\mathrm{HCl}$ or $\mathrm{H}_{2} \mathrm{SO}_{4}$.

\subsubsection{Magnet Pieces Leaching}

To test the effectiveness of FID vs. conventional CVAD on magnet pieces, cylindrical magnets were cut in half and put in with $7.5 \mathrm{~mL}$ of $3.2 \mathrm{~N}$ of $\mathrm{H}_{2} \mathrm{SO}_{4}$ for 15 min under various conditions (Table 8). The volume of acid and the molarity were adjusted to correlate with the number of moles required for the complete dissolution of the magnet mass used.

Table 8. Dissolved magnet mass after 15 min of contact time with $3.2 \mathrm{~N}$ of $\mathrm{H}_{2} \mathrm{SO}_{4}(n=3)$.

\begin{tabular}{cc}
\hline Conditions & Relative Dissolved Mass ${ }^{\text {a }}$ (\%) \\
\hline Room temp., without agitation & $5 \pm 2$ \\
Room temp., with agitation $^{b}$ & $5 \pm 2$ \\
CVAD & $34 \pm 5$ \\
FID & $62 \pm 2$ \\
\hline
\end{tabular}

a The coating of the magnets is not digested with the proposed methods and represents $1.9 \pm 0.2 \%$ of the total mass of the magnets. ${ }^{b}$ Agitation was performed by the magnets pieces themselves interacting with the magnet field of a stirring plate.

As observed with the ground magnet, once the optimal quantity of acid per gram of magnet is used, the temperature of the acid is a critical parameter for the rapid dissolution of unaltered magnets. These results support the idea that FID, as a powerful heating source, could be an effective method to rapidly dissolve NdFeB magnets for hydrometallurgical recycling.

To determine the required time for the complete dissolution of the magnet pieces by FID and CVAD, the amount of magnet digested was monitored as a function of digestion 
time (10 to $35 \mathrm{~min}$, Figure 4). The same parameters as previously described were used, but with $15 \mathrm{~mL}$ of $3.2 \mathrm{~N}$ of $\mathrm{H}_{2} \mathrm{SO}_{4}$ to avoid the complete evaporation of the acid due to an incomplete condensation of the acidic vapor inside the part of the digestion vessel surrounded by the Peltier cooling block. The temperature of $\mathrm{H}_{2} \mathrm{SO}_{4}$ was monitored using a thermocouple inserted into the solution while the lamps were on. It showed a working temperature of $103{ }^{\circ} \mathrm{C}$ after $1 \mathrm{~min}$, which is close to the expected boiling point of a $2 \mathrm{M}$ solution of $\mathrm{H}_{2} \mathrm{SO}_{4}\left(102{ }^{\circ} \mathrm{C}[26]\right)$.

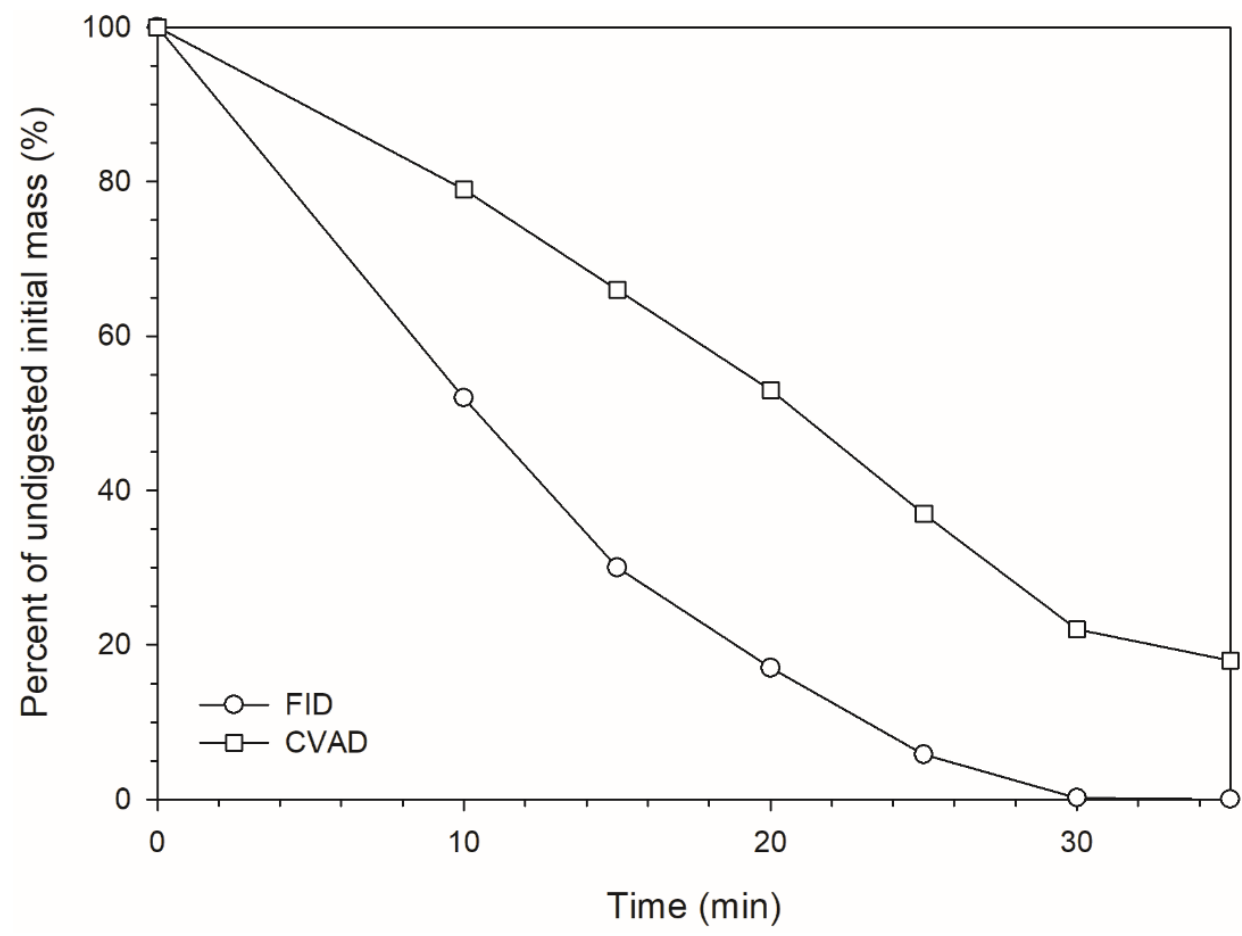

Figure 4. Undissolved magnet mass percentage after digestion in $\mathrm{H}_{2} \mathrm{SO}_{4}$ by FID and CVAD.

When the remaining magnet mass in the digestion vessel was approximately $10 \%$ of its initial value, the efficiency of the digestion tended to decrease for the FID approach. This is likely due to the round shape of the magnets used, which resulted in a smaller contact surface as the digestion progressed. Nonetheless, this experiment demonstrates that dissolution of magnet pieces is faster by FID than by CVAD.

\section{Conclusions}

The results obtained in this study indicate that focused infrared digestion (FID) could be used as an effective method for the recycling of rare earth magnets, either for the complete dissolution of ground samples (apart from refractory niobium oxides), or for the quantitative dissolution of REEs on magnetized and coarse magnet pieces. The absence of magnetic constituents in the FID unit enables the digestion of the magnets without any prior demagnetization process. The FID method is safer than others because, due to its rapid digestion time, FID does not require crushing of the magnets into fine powders. Skipping the grinding step also facilitates the separation of the undigested $\mathrm{Ni}-\mathrm{Cu}-\mathrm{Ni}$ coating and could potentially help in hydrometallurgical separation later in the recycling process.

Author Contributions: Conceptualization, M.B. and D.L.; methodology, M.B. and D.L.; formal analysis, M.B.; writing — original draft preparation, M.B.; writing-review and editing, F.-G.F. and D.L.; supervision, F.-G.F. and D.L.; project administration, D.L.; funding acquisition, F.-G.F. and D.L. All authors have read and agreed to the published version of the manuscript.

Funding: This research was funded by FRQNT_-Team Research Grant (2021 competition)_"Développement d'une filière hydrométallurgique de recyclage des métaux et des terres rares à partir des déchets de téléphones portables et de tablettes électroniques", grant number 284426. 
Institutional Review Board Statement: Not applicable.

Informed Consent Statement: Not applicable.

Data Availability Statement: The data presented in this study are available in this article.

Acknowledgments: The authors want to thank Vicky Dodier for her help with the grinding and sieving of the samples and Christa Bedwin for her editorial comments on the manuscript.

Conflicts of Interest: The authors declare no conflict of interest.

\section{References}

1. Forti, V.; Cornelis Peter, B.; Kuehr, R.; Bel, G. The Global E-Waste Monitor 2020: Quantities, Flows, and the Circular Economy Potential; United Nations University (UNU): Bonn, Germany; United Nations Institute for Training and Research (UNITAR): Geneva, Switzerland; International Telecommunication Union: Geneva, Switzerland; International Solid Waste Association: Rotterdam, The Netherlands, 2020; p. 120.

2. Zeng, X.L.; Mathews, J.A.; Li, J.H. Urban Mining of E-Waste is Becoming More Cost-Effective Than Virgin Mining. Environ. Sci. Technol. 2018, 52, 4835-4841. [CrossRef] [PubMed]

3. Ferron, C.J.; Henry, P. A review of the recycling of rare earth metals. Can. Metall. Q. 2015, 54, 388-394. [CrossRef]

4. Lister, T.E.; Wang, P.M.; Anderko, A. Recovery of critical and value metals from mobile electronics enabled by electrochemical processing. Hydrometallurgy 2014, 149, 228-237. [CrossRef]

5. Lixandru, A.; Venkatesan, P.; Jonsson, C.; Poenaru, I.; Hall, B.; Yang, Y.; Walton, A.; Guth, K.; Gauss, R.; Gutfleisch, O. Identification and recovery of rare-earth permanent magnets from waste electrical and electronic equipment. Waste Manag. 2017, 68, 482-489. [CrossRef] [PubMed]

6. Yang, Y.; Walton, A.; Sheridan, R.; Güth, K.; Gauß, R.; Gutfleisch, O.; Buchert, M.; Steenari, B.-M.; Van Gerven, T.; Jones, P.T.; et al. REE Recovery from End-of-Life NdFeB Permanent Magnet Scrap: A Critical Review. J. Sustain. Metall. 2016, 3, 122-149. [CrossRef]

7. Rademaker, J.H.; Kleijn, R.; Yang, Y.X. Recycling as a Strategy against Rare Earth Element Criticality: A Systemic Evaluation of the Potential Yield of NdFeB Magnet Recycling. Environ. Sci. Technol. 2013, 47, 10129-10136. [CrossRef]

8. Florek, J.; Giret, S.; Juere, E.; Lariviere, D.; Kleitz, F. Functionalization of mesoporous materials for lanthanide and actinide extraction. Dalton Trans 2016, 45, 14832-14854. [CrossRef]

9. Vander Hoogerstraete, T.; Blanpain, B.; Van Gerven, T.; Binnemans, K. From NdFeB magnets towards the rare-earth oxides: A recycling process consuming only oxalic acid. RSC Adv. 2014, 4, 64099-64111. [CrossRef]

10. Lee, C.H.; Chen, Y.J.; Liao, C.H.; Popuri, S.; Tsai, S.L.; Hung, C.E. Selective Leaching Process for Neodymium Recovery from Scrap Nd-Fe-B Magnet. Metall. Mater. Trans. A-Phys. Metall. Mater. Sci. 2013, 44A, 5825-5833. [CrossRef]

11. Helmeczi, E.; Wang, Y.; Brindle, I.D. A novel methodology for rapid digestion of rare earth element ores and determination by microwave plasma-atomic emission spectrometry and dynamic reaction cell-inductively coupled plasma-mass spectrometry. Talanta 2016, 160, 521-527. [CrossRef]

12. Rabatho, J.P.; Tongamp, W.; Takasaki, Y.; Haga, K.; Shibayama, A. Recovery of Nd and Dy from rare earth magnetic waste sludge by hydrometallurgical process. J. Mater. Cycles Waste Manag. 2013, 15, 171-178. [CrossRef]

13. Yoon, H.S.; Kim, C.J.; Chung, K.W.; Jeon, S.; Park, I.; Yoo, K.; Jha, M.K. The Effect of Grinding and Roasting Conditions on the Selective Leaching of Nd and Dy from NdFeB Magnet Scraps. Metals 2015, 5, 1306-1314. [CrossRef]

14. München, D.D.; Bernardes, A.M.; Veit, H.M. Evaluation of Neodymium and Praseodymium Leaching Efficiency from Postconsumer NdFeB Magnets. J. Sustain. Metall. 2018, 4, 288-294. [CrossRef]

15. Kumari, A.; Sinha, M.K.; Pramanik, S.; Sahu, S.K. Recovery of rare earths from spent NdFeB magnets of wind turbine: Leaching and kinetic aspects. Waste Manag. 2018, 75, 486-498. [CrossRef]

16. Tanvar, H.; Kumar, S.; Dhawan, N. Microwave Exposure of Discarded Hard Disc Drive Magnets for Recovery of Rare Earth Values. JOM 2019, 71, 2345-2352. [CrossRef]

17. Erust, C.; Akcil, A.; Tuncuk, A.; Deveci, H.; Yazici, E.Y. A Multi-stage Process for Recovery of Neodymium (Nd) and Dysprosium (Dy) from Spent Hard Disc Drives (HDDs). Miner. Process. Extr. Metall. Rev. 2021, 42, 90-101. [CrossRef]

18. Ciro, E.; Alzate, A.; López, E.; Serna, C.; Gonzalez, O. Neodymium recovery from scrap magnet using ammonium persulfate. Hydrometallurgy 2019, 186, 226-234. [CrossRef]

19. Kumari, A.; Jha, M.K.; Pathak, D.D. An innovative environmental process for the treatment of scrap Nd-Fe-B magnets. J. Environ. Manag. 2020, 273, 7. [CrossRef]

20. Berghof Products + Instruments GMBH. Microwave Digestion of Permanent Magnets; Application Note XT4; Eningen, Germany, 2020. Available online: https://www.berghof-instruments.com/en/application/microwave-digestion-of-permanent-magnets / (accessed on 14 July 2021).

21. Milliard, A.; Durand-Jezequel, M.; Lariviere, D. Sequential automated fusion/extraction chromatography methodology for the dissolution of uranium in environmental samples for mass spectrometric determination. Anal. Chim. Acta 2011, 684, 40-46. [CrossRef]

22. Yu, L.Q.; Wen, Y.H.; Yan, M. Effects of Dy and $\mathrm{Nb}$ on the magnetic properties and corrosion resistance of sintered NdFeB. J. Magn. Magn. Mater. 2004, 283, 353-356. [CrossRef] 
23. Le Breton, J.M.; Teillet, J. Mössbauer and X-ray study of NdFeB type permanent magnets oxidation: Effect of A1 and Nb addition. J. Magn. Magn. Mater. 1991, 101, 347-348. [CrossRef]

24. Prasad, V.; Baligidad, R.; Gokhale, A. Niobium and Other High Temperature Refractory Metals for Aerospace Applications. Aerosp. Mater. Mater. Technol. 2017, 267-288. [CrossRef]

25. Habashi, F. Extractive metallurgy of rare earths. Can. Metall. Q. 2013, 52, 224-233. [CrossRef]

26. Washburn, E.W.; West, C.J.; Dorsey, N.E.; National Research Council; International Research Council; National Academy of Science. International Critical Tables of Numerical Data, Physics, Chemistry and Technology; The National Academies Press: Washington, DC, USA, 1926. 